\title{
Extensão rural e intervenção: velhas questões e novos desafios para os profissionais
}

\author{
Eveline Favero ${ }^{1}$ e Jorge Castellá Sarriera ${ }^{2}$ \\ Universidade Federal do Rio Grande do Sul
}

\begin{abstract}
$\mathrm{O}$ artigo discute os desafios do contexto rural com os quais se deparam cotidianamente diferentes profissionais envolvidos com a prática da extensão. Utilizou-se a análise argumentativa como método para o tratamento dos dados, os quais foram coletados por meio da gravação de assembleia com alunos e ex-alunos do Curso de PósGraduação em Extensão Rural da UFSM, realizada no ano de 2005 em santa Maria, RS. O evento fez parte da programação do seminário comemorativo aos 30 anos de criação do curso. Participaram dele 23 pessoas. Os resultados do estudo foram divididos em três categorias de análise: a realidade rural, o perfil do extensionista e a formação em extensão rural. Cabe destacar que o meio rural não se configura como um espaço essencialmente agrícola. Logo, a preocupação do extensionista pura e exclusivamente com a técnica pode não estar sendo suficiente para atender a diversidade de necessidades de um novo contexto pluriativo e heterogêneo. $O$ trabalho interdisciplinar e a formação adequada configuram-se em desafios a serem alcançados pelos profissionais da área, além de que profissões como a psicologia podem ampliar seu campo de atuação e oferecer sua contribuição de modo a responder adequadamente às diferentes necessidades da população rural.
\end{abstract}

Palavras-chave: Extensão rural, Psicologia, Intervenções.

Rural extension and intervention: old issues and new challenges for professionals

The article discusses the challenges of the rural context that are faced on a daily basis by various professionals involved in the practice of rural extension. Argumentative analysis is used as a method for the treatment of data, which were collected by recording interviews made with students and alumni of the Graduate Studies Program in Rural Extension of the Federal University of Santa Maria, Brazil. The interviews were made in December of 2005 in Santa Maria, state of Rio Grande do Sul. The event was part of a seminar held to celebrate the $30^{\text {th }}$ anniversary of the course's creation. 23 persons participated in it. The results were divided into three categories of analysis: the rural reality, the profile of rural extension practitioners and the training in rural extension. It should be highlighted that the rural environment does not consist of an essentially agricultural space. Thus, the rural extension practitioner's sole concerned with technique may not be enough to meet the diversified needs of a poly-active and heterogeneous context. Interdisciplinary work and an adequate training constitute challenges to be faced by the professionals of this area. Furthermore, a discipline such as psychology should extend its field of activities and make a contribution to adequately respond to the different needs of the rural population.

Keywords: Rural extension, Psychology, Interventions.

\section{Introdução}

$\mathrm{O}$ artigo trata da temática da extensão rural e tem como eixos de discussão a realidade rural, o perfil do extensionista e a formação em extensão rural. Primeiramente faz-se breve revisão de literatura e, na sequência, a análise dos dados e a discussão dos resultados do estudo.

Nos debates sobre a temática da extensão rural, duas críticas estão frequentemente presentes: os resultados negativos da Revolução $V_{e r d e}^{3}$ e os problemas evidenciados nos

1 Psicóloga. Mestre em extensão rural pela Universidade Federal de Santa Maria. Doutoranda em psicologia pela Universidade Federal do Rio Grande do Sul.

2 Psicólogo. Doutor em Psicologia. Professor Adjunto da Universidade Federal do Rio Grande do Sul.

3 A "Revolução Verde" teve sua origem em 1943 com estudos da fundação Rockfeller estabelecida no México, os quais buscavam o melhoramento de cultivos alimentares como o milho e o trigo. Pesquisadores americanos e mexicanos realizaram uma série de experimentos essencialmente dirigidos para obter o cruzamento de novas variedades de trigo e milho, objetivando que elas 
modelos convencionais baseados no difusionismo ${ }^{4}$. É o que, por exemplo, encontramos na Política Nacional de Assistência Técnica e Extensão Rural (ATER), conforme o Ministério do Desenvolvimento Agrário (2004).

A política de ATER propõe uma nova abordagem para a Extensão Rural, com o objetivo de romper com a proposta difusionista. Nessa abordagem, a realidade passa a ser compreendida de maneira sistêmica e o paradigma tecnológico a ser adotado pelo extensionista baseia-se nos princípios da agroecologia. Além disso, elege como público preferencial os agricultores familiares ${ }^{5}$ e como elemento central de suas ações, a busca da inclusão social da população rural brasileira mais pobre.

Juntamente com as orientações teóricas e técnicas, a política de ATER destaca um novo perfil de extensionista. Este precisa ter conhecimentos e habilidades compatíveis com a sua proposta metodológica, ou seja, trabalhar de maneira participativa, desempenhando um papel educativo e atuando como animador e facilitador de processos de desenvolvimento rural sustentável.

Farrington, Christoplos, Kidd e Beckman (2002) referiram-se à extensão rural tradicional como essencialmente focada na produção, institucionalmente monolítica, diretamente centralizada e estruturada nas premissas do setor público. Em um contexto de escassez de recursos, a extensão rural brasileira, de caráter público, vê-se diante da necessidade de reorientar seus objetivos e destinatários. Desse modo, passa a ser endereçada prioritariamente às necessidades dos pobres rurais, os quais não são apenas produtores, mas também trabalhadores e consumidores (Farrington et al., 2002), o que requer uma reorientação das práticas voltadas exclusivamente para a produção. A inserção de novas tecnologias agrícolas implica na análise de que elas venham não apenas a aumentar a produtividade, mas também promover crescimento nas oportunidades de emprego e contribuir para a redução da vulnerabilidade social dos agricultores.

Tal preocupação denota a necessidade de uma nova forma de fazer extensão, diante da organização do rural enquanto espaço social. De acordo com Anjos (2003), o espaço rural tem se tornado pluriativo, de modo que as famílias combinam usualmente rendas agrícolas e extraagrícolas, através de atividades realizadas dentro e fora das próprias explorações. Esse mecanismo de adaptação das explorações familiares, segundo o autor, demonstra a crescente dificuldade de reprodução no marco estrito e exclusivo da atividade agrícola e das rendas que esta permite obter. Por outro lado, a pluriatividade demarca uma nova concepção do rural, configurando-o não mais num espaço exclusivamente agrário (Graziano da Silva, Del Grossi \& Campanhola, 2002).

Outro desafio para a extensão rural pública é a necessidade de operar efetivamente no nível das comunidades em áreas remotas. Essa realidade leva à emergência de uma extensão rural pluralista, ou seja, o setor público acaba por dividir espaço com os chamados "paraextensionistas" (representantes de grupos comunitários e de ONGs). De acordo com Farrington et al. (2002), a necessidade de preencher as carências deixadas pelo setor público pode levar a efeitos indesejáveis para essas comunidades, pois diante das necessidades dos

produzissem mais grãos que as variedades crioulas e que tivessem alta resistência às condições culturais de terras do trópico e do sub-trópico. De acordo com Beltrán (1971): "A produtividade das novas sementes é tão espetacular, sua difusão em vários países do mundo tem sido tão rápida e as consequências que dela derivam são tão importantes que esse processo veio a ser denominado 'Revolução Verde'"' (p. 5).

4 A teoria da difusão de inovações norteia a ação do extensionista no sentido de transmitir conhecimentos tecnológicos a setores da população rural (os produtores) que deles carecem. A partir dessa teoria, acredita-se que a mudança de comportamento dos indivíduos, ou seja, sua adesão efetiva a uma inovação tecnológica só se dá com a mudança de mentalidade dos receptores. Uma das críticas fortes a essa teoria é o seu caráter reducionista, uma vez que busca explicar a realidade social apenas do ponto de vista psicológico dos sujeitos (Pinto, 1973).

$5 \mathrm{O}$ termo agricultores familiares refere-se, no debate acadêmico, aos grupos sociais com pequenas extensões de terra e que utilizam fundamentalmente o trabalho da família na execução dos processos produtivos (Schneider, 1999). 
pobres a serem supridas, abre-se a porta para o uso abusivo do poder pelas elites e pelas instituições locais.

Somando-se a isso, nas áreas integradas rural-urbano são significantes os riscos causados pelas trajetórias de desenvolvimento rural desordenado e é potencial o crescimento da pobreza nessas localidades. Nelas encontramos pessoas que resultam do êxodo rural massivo ocasionado pela modernização da agricultura, na qual não puderam se integrar e tampouco responder às rápidas mudanças do mercado de trabalho urbano. Para Farrington et al. (2002), a redução da vulnerabilidade deve ser o mais realístico objetivo da extensão rural para essas áreas marginais, nas quais também é difícil intervir tecnicamente, uma vez que não é possível encontrar um público de categorias fixas nesse contexto ${ }^{6}$.

Diante de tamanhos desafios que se colocam para o extensionista rural, é oportuno pensar o que se entende por "extensão rural". De acordo com Castro (2003), em sua origem latina o termo "extensão" faz referência a um estender ou desdobrar (tendere) para fora (ex): "Se trata então de uma ação que tem por objeto o outro, sobre o qual se descarrega o conteúdo que o ator ou a fonte deseja transmitir" (p. 51). Devido a esse significado do termo, Freire (1977) considerou-o inadequado para designar o trabalho indispensável de ordem técnica e humanista que caberia ao agrônomo desenvolver.

Castro (2003) afirma que o termo extensão pressupõe uma intenção que se encontra na fonte, porém nem sempre no receptor. Ela responde a uma necessidade de quem a realiza, a qual está baseada na percepção da carência do receptor e na convicção da fonte de que pode fazer algo por ele. O poder fazer implica em alguma forma de intervenção na realidade do outro, o qual não solicitou essa intervenção. Por isso, a fonte precisa desenvolver um processo de informação para que o receptor convença-se de que a intervenção é importante. Desse modo,

se chega a uma "extensão" que se assemelha mais a uma relação de mercado (envolvendo dispositivos de publicidade, de oferta e demanda, de sistemas de informação) que a uma disponibilidade para responder aos que se interessam pelos conteúdos que se tem condições de "extender" (Castro, 2003, p. 52).

No entanto, para Freire (1977), a extensão rural não é isso. A extensão é um ato educativo e, por isso, não se pode negar para aqueles que atuam nesse campo, mais precisamente ao agrônomo,

o direito de ser um educador-educando, com os camponeses educandos-educadores. Pelo contrário, precisamente porque estamos convencidos de que este é o seu dever, de que esta é a sua tarefa de educar e de educar-se, não podemos aceitar que seu trabalho seja rotulado por um conceito que o nega (p. 23).

Castro (2003) identificou três modelos diferentes do que hoje pode-se chamar de extensão, os quais estão baseados na ação extensionista e nas diferentes concepções de seus atores, bem como de seus destinatários.

O primeiro modelo é a extensão como participação, ou seja, o extensionista é um mediador de conhecimentos e os compartilha com quem se interessa por eles. A atitude básica da extensão é que ela é uma proposta, um convite aberto a todos os que desejam compartilhála. Não é do interesse da fonte persuadir ou convencer ao receptor, apenas oferecer uma alternativa que considera interessante e até fundamental, mesmo que o receptor não a considere assim (Castro, 2003).

No segundo modelo a extensão é compreendida como serviço. Nesta concepção a fonte se reconhece como portadora de um domínio do qual pensa que carece o receptor e que na 
verdade não é mero receptor, mas procurador ativo de uma solução para seu problema a um especialista que se espera que possa ter uma resposta adequada. A diferença daquele primeiro modelo é que neste não interessa à fonte difundir o conhecimento a todo mundo, mas aplicá-lo de maneira específica. A fonte não busca persuadir ao receptor, afirmou Castro (2003), apenas se limita a informar com orientação técnica e que espera seja seguida pelo receptor.

Para os adeptos do terceiro modelo, a extensão requer a intervenção. Esta é a modalidade que se observa com mais frequência nos organismos públicos encarregados da extensão rural. Neste modelo, a fonte não está disposta a discutir os conteúdos que serão transmitidos, pois eles são baseados em comprovações científicas incontestáveis. Chega-se a uma hipervalorização dos conteúdos, pois se acredita que eles beneficiem diretamente os agricultores e indiretamente a sociedade. A ação extensionista é válida em si mesma, por isso, os receptores devem ser persuadidos a aceitar suas propostas. Neste modelo o agente é um facilitador, desempenha seu trabalho como dever e obrigação, procura seguir as orientações da instituição à qual está vinculado, buscando o acatamento de suas intervenções pelos receptores (Castro, 2003).

Diante dessas considerações teóricas pode-se verificar que é amplo o campo de discussão sobre a temática da extensão rural. Partindo de dados empíricos, este artigo discute questões como a realidade rural, o perfil do extensionista e as dificuldades de seu trabalho, além de aspectos referentes à sua formação.

\section{Procedimentos metodológicos}

Os dados aqui apresentados foram coletados por meio da gravação da assembleia que fez parte da programação do seminário comemorativo aos trinta anos da criação do curso de pós-graduação em extensão rural da Universidade Federal de Santa Maria (UFSM). A assembleia ocorreu em 30 de novembro de 2005. Os participantes autorizaram tal procedimento, cientes de que os resultados poderiam vir a ser publicados.

Participaram da assembleia vinte e três pessoas, sendo elas estudantes de mestrado e ex-alunos do curso de pós-graduação em extensão rural da UFSM. Estes últimos distribuíam-se entre profissionais da extensão, pesquisadores e professores da área em diferentes locais do Brasil e de outros países da América Latina.

Três temáticas foram apresentadas para discussão na assembleia, a saber: como se apresenta a realidade rural em relação aos desafios do trabalho em extensão rural, que perfil o extensionista deve ou deveria ter e porque haveria a necessidade de se criar um doutorado na área. A gravação da discussão foi posteriormente transcrita na íntegra para fins de análise.

O método utilizado no tratamento dos dados foi a análise argumentativa. A técnica foi escolhida, pois na leitura da transcrição verificou-se que as pessoas que se manifestaram durante a assembleia emitiam sua opinião sobre a temática em discussão e argumentavam sobre ela. Algumas vezes contrapunham-se à opinião de outros participantes ou salientavam exceções à regra de sua própria opinião. Essa avaliação levou à compreensão de que por detrás dos argumentos dos participantes havia uma ideia central, ou opinião central, a ser defendida ou confrontada, a qual poderia estar explícita ou implícita no discurso.

A análise argumentativa é uma técnica qualitativa que objetiva documentar a maneira como afirmações são estruturadas dentro de um texto discursivo. Centra-se, normalmente, na interação entre duas ou mais pessoas que apresentam argumentos como parte de uma discussão ou debate, ou sobre um texto dentro do qual a pessoa constrói um argumento. O argumento representa a ideia central ou o princípio no qual a fala está baseada. O termo argumentação 
para Van Eemeren et al. (1987, citado por Liakopoulos, 2002) "[...] se refere a uma atividade verbal ou escrita que consiste em uma série de afirmações com o objetivo de justificar ou refutar, determinada opinião, e persuadir uma audiência" (p. 219).

A argumentação possui características básicas de acordo com Burleson (1992, citado por Liakopoulos, 2002), sendo elas: a existência de uma asserção construída como proposição, uma estrutura organizativa ao redor da defesa da proposição e um salto inferencial no movimento que vai da justificativa à asserção.

A análise argumentativa utilizada neste estudo segue a proposta de Toulmin (1958, citado por Liakopoulos, 2002), o autor apresenta como estrutura de um argumento a seguinte constituição:

Uma proposição ou uma conclusão precedida por fatos (dados) que a apoiam. Mas muitas vezes um qualificador dos dados é exigido: em outras palavras, uma premissa que nós usamos para defender que os dados são legitimamente empregados para apoiar a proposição. Esta premissa é chamada de garantia. Garantias são cruciais na determinação da validade do argumento, porque elas justificam explicitamente o passo que se deu dos dados para a proposição, e descrevem o processo em termos de por que esse passo pode ser dado (p. 220).

Além dos dados (fatos ou evidências que estão à disposição do criador do argumento), da proposição (uma afirmação que contém uma estrutura e é apresentada como o resultado de um argumento apoiado por fatos), da garantia (uma premissa consistindo de razóes, autorizações e regras usadas para afirmar que os dados são legitimamente utilizados a fim de apoiar a proposição), podemos encontrar na estrutura do argumento o apoio e a refutação. Apoio é uma premissa usada como um meio de auxiliar na garantia do argumento, oferecendo normalmente informação explícita através de exemplos, enquanto que a refutação é uma premissa que mostra a exceção da regra afirmada no argumento, autorizando a refutação da generalidade da garantia (Toulmin, 1958, citado por Liakopoulos, 2002).

A análise argumentativa do material em questão (a transcrição de gravação da assembleia) seguiu os seguintes passos: 1) criação de três categorias para agrupar os diferentes argumentos, as quais foram determinadas a priori por meio dos eixos de discussão da assembleia; 2) desconstrução da estrutura dos argumentos dos diferentes participantes que se manifestaram na discussão e distribuição desses argumentos de acordo com as categorias; 3) agrupamento de argumentos semelhantes ou idênticos em subcategorias de análise; 3) análise das subcategorias e discussão dos resultados. As falas dos participantes no processo de identificação e desconstrução dos argumentos foram mantidas na medida do possível, introduzindo-se apenas, quando necessário, elementos de ligação importantes na compreensão do discurso ou organizando a fala em sentenças curtas e diretas.

É importante considerar o contexto em que aconteceu a assembleia, ou seja, como parte integrante de um seminário. No decorrer do evento, diferentes questões haviam sido levantadas por palestrantes e debatedores, dentre as quais as discutidas na assembleia, o que pode ter influenciado significativamente a argumentação dos participantes. Desse modo, os resultados aqui apresentados poderão dizer respeito muito mais a uma tendência de discussão do que a opinião particular dos participantes.

\section{Resultados e discussões}

Os resultados do estudo serão representados por meio de três categorias de análise, as quais se referem aos eixos de discussão da assembleia. A primeira categoria trata da avaliação 
dos participantes sobre a realidade rural, ou seja, como ela se apresenta diante de quem está trabalhando no campo da extensão rural, bem como para quem realiza pesquisas na área. A segunda categoria faz referência ao perfil do extensionista e parte da opinião dos participantes sobre as dificuldades e os desafios que emergem na formação e no trabalho. A terceira categoria trata da compreensão dos participantes sobre a criação de um doutorado em extensão rural, sobre o que ele deveria contemplar, se é que haveria a necessidade da sua criação.

Cabe esclarecer que as discussões da assembleia foram norteadas pelos três eixos temáticos. Nem todos os participantes deram sua opinião sobre cada temática, uma vez que isso ocorreu de maneira livre. A representação dos argumentos diz respeito não à fala de todos os participantes, mas somente daqueles que emitiram sua opinião.

\section{Representação dos argumentos sobre a realidade rural}

Dentre os argumentos dos participantes sobre a realidade rural emitidos pelos participantes, quatro podem ser considerados centrais: argumento 1, "A realidade rural se apresenta de maneira diferenciada" ; argumento 2, "A extensão rural é também responsável pela condição social dos agricultores" ; argumentos 3, "A extensão rural carece de métodos adequados para interpretar a realidade" e 4, "A extensão rural tem erros teóricos e não metodológicos". Tais argumentos serão discutidos individualmente a seguir.

Quadro 1. Argumento 1: "A realidade rural se apresenta de maneira diferenciada".

\begin{tabular}{|c|c|}
\hline Dados & Proposições (deste modo) \\
\hline 1. Em função do tamanho do Brasil, características da & 1. A realidade rural é bastante diferente. \\
\hline paisagem, do relevo e sócio-culturais. & 2. O meio rural se apresenta com uma enorme diferenciação \\
\hline 2. No campo agroecológico a gente reconhece primeiro a & social. \\
\hline diferenciação social presente no meio rural. & 3. O meio rural é heterogêneo. \\
\hline $\begin{array}{l}\text { 3. Há uma diversidade de sistemas de produção, há uma } \\
\text { diversidade de formas culturais, há uma diversidade de }\end{array}$ & $\begin{array}{l}\text { 4. Existem tantas quantas realidades rurais quanto os agentes } \\
\text { sociais possam construir. }\end{array}$ \\
\hline $\begin{array}{l}\text { elementos geográticos, de clima, de solo, de vegetação. } \\
\text { 4. A realidade rural é uma construção social. }\end{array}$ & $\begin{array}{l}\text { 5. A agricultura é para muitas famílias uma atividade } \\
\text { complementar. }\end{array}$ \\
\hline $\begin{array}{l}\text { 5. Alguns agricultores que a gente considera e o governo na } \\
\text { verdade não são mais agricultores. }\end{array}$ & 6. As necessidades dos agricultores são diferenciadas. \\
\hline 6. Os agricultores podem ser divididos em vários extratos. & \\
\hline & Apoios (porque) \\
\hline Garantias (pois) & 1. A gente pensa em tecnologias super-avançadas, super- \\
\hline 1. Mesmo dentre os agricultores familiares existem diferenças. & modernas, intensivas em capital enquanto que alguns \\
\hline $\begin{array}{l}\text { 2. A diferenciação social não tem que ser um motivo da gente } \\
\text { ligar necessariamente coisas que são boas. }\end{array}$ & $\begin{array}{l}\text { agricultores familiares não estão preparados nem para se } \\
\text { locomover, não sabem manejar tecnologias. }\end{array}$ \\
\hline 3. A heterogeneidade nos ajuda a intervir, porque nós não & 2. Desigualdade social se apresenta como diferenciação social. \\
\hline $\begin{array}{l}\text { vamos ter modelos e sim formas de ver o movimento da } \\
\text { agricultura ajustado a heterogeneidade. }\end{array}$ & $\begin{array}{l}\text { 3. A heterogeneidade se dá em regiões e em algumas ela é } \\
\text { mais forte. }\end{array}$ \\
\hline $\begin{array}{l}\text { 4. As realidades são muito particulares dependendo do grupo } \\
\text { social que vai fazer esta leitura. A base para entender as } \\
\text { diversas realidades é a questão do conflito. }\end{array}$ & $\begin{array}{l}\text { 4. Esse discurso do meio rural que é pluriativo, que é } \\
\text { multidimensional oculta a questão de que existem diversas } \\
\text { verdades. }\end{array}$ \\
\hline $\begin{array}{l}\text { 5. As famílias estão sobrevivendo de outras rendas principais } \\
\text { e têm a agricultura em segundo plano. }\end{array}$ & \\
\hline $\begin{array}{l}\text { 6. Tem agricultores que passam fome e têm agricultores que } \\
\text { não são agricultores para as políticas públicas. }\end{array}$ & \\
\hline
\end{tabular}

O argumento 1 reflete a visão sistêmica proposta pela política de ATER como ponto de partida para a compreensão da realidade rural. $\mathrm{O}$ entendimento da realidade como diferenciada supõe que o extensionista deva conhecer essas diferenciações do seu campo de atuação e que também suas intervenções sejam adequadas a cada realidade. Contrapõe o discurso dos pacotes 
tecnológicos, ou seja, quando o extensionista levava até o agricultor um proposta pronta, sendo que este último era quem deveria adaptar-se. Nesta outra visão, a intervenção é que tem que se adaptar à realidade e aos recursos do agricultor (Dufumier, 1996). Esse fato acaba por exigir que o extensionista compreenda a racionalidade de cada agricultor, o porque de suas atitudes e de que forma podem ser introduzidas mudanças que não provoquem impactos negativos ou desestruturem a organização interna da unidade produtiva.

Por outro lado, a ideia de diferenciação social apresentada no argumento 1 converge com o discurso da pluriatividade. Neste, as diferenciações que foram se estabelecendo ao longo do tempo, como por exemplo, diferentes ocupações desempenhadas pelas famílias residentes no meio rural, algumas delas de caráter urbano, são tidas como formas de garantir sobrevivência e conter o êxodo rural e, por isso, estimuladas. A ressalva que deve ser feita é a de que essa realidade possa ser um reflexo de um contexto social que não oferece condições suficientes para que as famílias permaneçam na agricultura, obrigando-as a desempenhar outras atividades para garantir sua sobrevivência (Anjos, 2003).

Quadro 2. Argumento 2: “A extensão rural é também responsável pela condição social dos agricultores".

\begin{tabular}{|l|l|}
\hline $\begin{array}{l}\text { Dados } \\
\begin{array}{l}\text { 1. A agricultura tradicional, convencional, capitalista ela vai } \\
\text { ter cada vez menos necessidade de produtores, necessidade de } \\
\text { áreas. Ela vai se tornar um processo cada vez mais seletivo. }\end{array}\end{array}$ & $\begin{array}{l}\text { Proposições (deste modo) } \\
\text { 1. A extensão rural contribuiu no processo de exclusão dos } \\
\text { agricultores. }\end{array}$ \\
$\begin{array}{l}\text { Garantias (pois) } \\
\text { 1. A extensão rural não estimulou a diversificação produtiva. }\end{array}$ & $\begin{array}{l}\text { Apoios (porque) } \\
1 . \text { Hoje nós temos agricultores com dieta alimentar precária. }\end{array}$ \\
\hline
\end{tabular}

Neste argumento aparecem colocações quanto aos resultados das práticas da extensão rural tradicional. A modernização da agricultura não contemplou todas as camadas de agricultores, contribuindo assim para o crescimento da pobreza e da exclusão social. Vale lembrar que, segundo Farrington et al. (2002), a preocupação da extensão rural tradicional é a produção agrícola. Porém, o meio rural não é composto apenas de produtores. Nele encontramos também trabalhadores e consumidores. No entanto, a modernização da agricultura não esteve atrelada à qualificação profissional dos trabalhadores nem à segurança alimentar, pois estimulou o cultivo comercial em detrimento do cultivo de subsistência. A extensão, para os autores, é o principal fator que influencia mudanças no mercado de trabalho rural. O conhecimento dos seus impactos positivos e negativos nos ganhos dos pobres requer consciência e análise nas relações entre mudanças tecnológicas e mercado de trabalho, bem como entre estas e a segurança alimentar das populações rurais.

No entanto, responsabilizar a extensão rural pela condição social dos agricultores pode configurar-se como um equívoco. A prática da extensão rural parte de modelos políticos para a agricultura, como, por exemplo, o da modernização agrícola. No período de 1960-1970, o Brasil foi marcado pela industrialização da agricultura, através da expansão da grande empresa capitalista na agropecuária brasileira. Entendia-se a agricultura brasileira como atrasada, o que serviria de empecilho ao desenvolvimento. Milhares de pequenas unidades de produção desapareceram nesse período (Graziano da Silva, 1985), dando lugar às grandes lavouras mecanizadas.

Desse modo, para Graziano da Silva (1985), a miséria atual de agricultores familiares e demais categorias encontradas no meio rural, tem suas raízes na pressão de grandes proprietários, comerciantes ou usurários, na presença de grandes capitais controlando a venda de insumos e a compra de produtos. Enfim, a situação precária encontrada no meio rural é o 
resultado de um modelo político de desenvolvimento econômico do país que norteou a prática da extensão rural por um longo período, do qual ainda encontramos alguns resquícios.

Quadro 3. Argumento 3: "A extensão rural carece de métodos adequados para interpretar a realidade".

\begin{tabular}{|l|l|}
\hline $\begin{array}{l}\text { Dados } \\
\text { 1. 'Pipoca' um grande número de métodos que não dão conta } \\
\text { de interpretar a realidade. }\end{array}$ & $\begin{array}{l}\text { Proposição (deste modo) } \\
1 . \text { A extensão vive uma crise de métodos para interpretar a } \\
\text { realidade. }\end{array}$ \\
$\begin{array}{l}\text { Garantia (pois) } \\
\begin{array}{l}1 . \text { Devido à crise de métodos têm-se dificuldades de definir } \\
\text { estratégias de intervenção. }\end{array}\end{array}$ & $\begin{array}{l}\text { Apoio (porque) } \\
\text { 1. As intervenções devem levar em consideração as diferenças } \\
\text { e serem apropriadas a cada realidade. }\end{array}$ \\
\end{tabular}

A questão metodológica configura-se em uma das maiores dificuldades e é frequentemente enfatizada pelos extensionistas oriundos das ciências agrárias. Sobre a adequação do método, Sarriera (2008) afirmou que "iniciar uma atividade comunitária exige uma adequada planificação. Essa planificação deve ter uma boa sustentação teórico-conceitual que oriente a ação e um bom conhecimento da realidade" (p. 137). Este último pode ser alcançado por meio da análise das suas necessidades, a qual deve acontecer como atividade inicial, dentro de um processo de investigação ação participante (IAP), conforme Montero (1994). O objetivo dessa análise é:

transformar as necessidades percebidas (cognitivamente), em necessidades sentidas (cognitiva e afetivamente, ou conscientizadas). Neste sentido a comunidade pode perceber, mas não sentir uma necessidade, possivelmente por estar embotada pelos meios de comunicação social ou pela naturalização daquilo que para os investigadores externos seria objeto de grande preocupação, bloqueando sua capacidade de pensar analiticamente, colocando em termos ideológicos um conhecimento determinado de antemão, que busca conformar as pessoas segundo os interesses dominante (Sarriera, 2008, pp. 138-139).

O autor enfatiza que "o conhecimento da comunidade, de seu espaço físico, seus costumes e seu cotidiano, facilitará a inserção e o diálogo para o levantamento de necessidades [...]" (pp. 137-138). Desse modo, a proximidade (estreitamento de laços) do profissional na comunidade em que trabalha e o estabelecimento do diálogo colocam-se como atitudes fundamentais no reconhecimento de suas reais necessidades. Não se trata apenas de aplicar um método adequado de levantamento de necessidades, mas de estabelecer a priori uma relação próxima e dialógica, que lance as bases para todo o trabalho subsequente de intervenção, seja ela para um grupo de pessoas ou para um agricultor em específico.

Quadro 4. Argumento 4: "A extensão rural tem erros teóricos e não metodológicos".

\begin{tabular}{|l|l|}
\hline $\begin{array}{l}\text { Dados } \\
\text { 1. A diferenciação social, a pluriatividade, o êxodo rural são } \\
\text { frutos do poder econômico. }\end{array}$ & $\begin{array}{l}\text { Preposição (deste modo) } \\
1 . \text { A extensão rural tem erros teóricos e não metodológicos. } \\
\text { Apoio (porque) } \\
\text { Garantia (pois) } \\
\begin{array}{l}\text { 1. Toda metodologia tem a ver com a teoria. } \\
\text { capto a realidade, de uma forma adequada eu posso ter } \\
\text { qualquer metodologia, mas provavelmente, com a minha } \\
\text { metodologia eu não modifico a realidade enquanto eu não } \\
\text { modificar como eu entendo a realidade. }\end{array}\end{array}$ \\
\end{tabular}


A preocupação de que os métodos utilizados na extensão rural para se fazer a leitura da realidade possam ser inadequados é contraposta com a argumentação de que os erros seriam teóricos e não metodológicos (argumento 4).

O extensionismo vivenciou um período em que os profissionais recebiam as ações de extensão prontas, as quais deveriam ser colocadas em prática sem a preocupação de compreender a realidade. $O$ seu papel, dentro do modelo difusionista, era o de levar o conhecimento até o agricultor, ou seja, aquele que "não o tem". Caso a ação não obtivesse êxito, a responsabilidade era atribuída ao agricultor, por não seguir corretamente as orientações técnicas, e nunca ao extensionista e muito menos às instituições de extensão rural.

Diante do desafio de repensar as suas práticas, o extensionismo cai no que chamamos de "crise da extensão rural". Castro (2003) afirma que "não é a extensão rural que está em crise, mas a nossa forma de pensar a extensão rural" (p. 41). De certo modo, essa crise não é vivida por todos os modelos apresentados pelo autor: extensão como participação, extensão como serviço e extensão como intervenção. É provável que este último modelo seja o que realmente experimente a crise de métodos e de teorias, uma vez que as intervenções têm seu foco especificamente no conteúdo e muito pouco no contexto social.

\section{Representação dos argumentos sobre o perfil do extensionista rural}

Quanto ao perfil do extensionista rural, identificou-se, na fala dos participantes que se pronunciaram, um total de seis argumentos centrais, o que significa dizer que nesta categoria houve uma diversidade de opiniões. Os argumentos são: argumento 1, "O extensionista precisa fazer uma leitura adequada da realidade social"; argumento 2, "O extensionista precisa saber manejar conflitos"; argumento 3, "O extensionista está fugindo da questão da tecnologia"; argumento 4, "É necessário repensar o ensino da extensão rural na pós-graduação"; argumento 5, "O extensionista precisa participar das instituições que pensam suas ações" e argumento 6 , "Precisa-se dar mais atenção à extensão rural na graduação".

Quadro 5. Argumento 1: "O extensionista precisa fazer uma leitura adequada da realidade social".

\begin{tabular}{|l|l|}
\hline $\begin{array}{l}\text { Dados } \\
\text { 1. Conforme o grupo social que está analisando a realidade, a } \\
\text { leitura é diferente. }\end{array}$ & $\begin{array}{l}\text { Proposição (deste modo) } \\
\text { 1. O extensionista precisa contribuir no processo de leitura } \\
\text { social e ver quais grupos sociais pode identificar. } \\
\text { 2. A realidade social se expressa numa forte diferenciação } \\
\text { social. }\end{array}$ \\
$\begin{array}{l}\text { 2. O extensionista precisa ter sensibilidade social, ou } \\
\text { compromisso social, saber em que problema ele está atuando. }\end{array}$ \\
$\begin{array}{l}\text { 1. Dizer que a realidade é complexa é o mesmo que dizer } \\
\text { nada. }\end{array}$
\end{tabular}

Neste argumento, ao extensionista é atribuído o papel de contribuir na leitura adequada da realidade social. O perfil do extensionista exige "sensibilidade social", "compromisso social". Conhecer a realidade social significa conhecer além da realidade rural, é inseri-la em um contexto mais amplo. Essa tarefa supõe que o extensionista não seja apenas um técnico encarregado de soluções específicas para problemas específicos. Ele precisa também conhecer o seu campo de atuação, as relações que nele se estabelecem, os interesses presentes e as possibilidades de mudança social. Nesse sentido, a tarefa da extensão aparece como bem mais ampla do que se propunha tradicionalmente, quando o foco era essencialmente a produção agrícola, propondo um espaço no qual profissionais de diferentes áreas estariam habilitados a dar sua contribuição. 
Quadro 6. Argumento 2: "O extensionista precisa saber manejar conflitos".

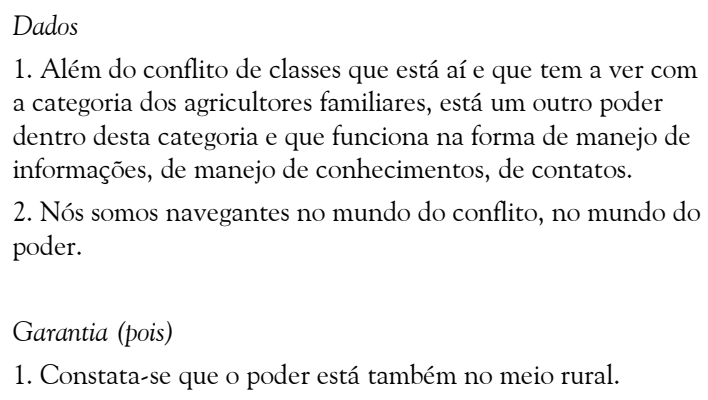

\section{Preposição (deste modo)}

1. O extensionista precisa democraticamente resolver conflitos para depois intervir.

Apoio (porque)

1. Se pensarmos como o poder funciona, como é que é a ideologia, como é que funcionam os veículos de comunicação identificaremos a presença do poder no meio rural.

Para Montero (2003), o poder atravessa todas as relações humanas. De um ou de outro modo, está sempre presente nelas, sob muitas formas, às vezes mais sutis, outras mais explícitas. No poder existem aspetos tanto positivos, quanto negativos. $O$ poder é um problema não somente quando é exercido abusivamente em um marco dominante e opressor, mas também quando se ignora que o possuímos.

Segundo a autora, o profissional que trabalha no nível da comunidade deve catalisar a organização e as ações necessárias para que a comunidade use seus recursos, reconheça e empregue seu poder, ou busque outros recursos e desenvolva novas capacidades, gerando assim o processo a partir dela mesma? . O controle das ações e o poder devem estar centrados na comunidade. Acostumamo-nos a pensar o poder como algo polarizado, os que têm e os que não têm. Diversas situações sociais demonstram que camadas populares detêm poder, então, o que pode na verdade encontrar-se polarizado em algum momento é o exercício do poder e não o próprio poder (Montero, 2003).

Medeiros (1989) apresenta um esboço histórico das lutas do campesinato brasileiro por melhores condições de vida e de trabalho, por preços justos, por terra e, acima de tudo, por dignidade. Tal esboço denota que historicamente essa classe social detinha consciência das questões de poder que estavam envoltas em sua realidade social. No entanto, a história brasileira é uma história urbana e tais questões frequentemente não são mencionadas:

A própria trajetória desses trabalhadores - explorados, subordinados politicamente aos grandes proprietários, excluídos dos mais elementares direitos políticos e sociais - implica na dificuldade de preservação de sua memória social. A imagem que herdamos do homem do campo é uma versão construída pelos vencedores no processo histórico. De acordo com ela fomos, durante muito tempo, levados a pensar o trabalhador rural como passivo, submisso, cordato, incapaz de formular seus próprios interesses e lutar por eles (Medeiros, 1989, p. 11).

Essa afirmação aponta para o fato de que o desrespeito aos mínimos direitos sociais e a situação de pobreza e exclusão desses trabalhadores, embora se perpetue até hoje, não se configura como um indicativo de submissão e passividade. As trajetórias históricas das lutas camponesas reafirmam o lugar de não-cidadão imposto a essa categoria no interior da sociedade (Medeiros, 1989), ao mesmo tempo em que denota a consciência de que as questões de poder estiveram sempre presente na história do espaço agrário brasileiro.

O conhecimento do extensionista carrega certa parcela de poder. Todavia, o agricultor também o possui. Outros poderes estão presentes nessa realidade, como o que sutilmente oprime. Porém, se cabe ou não ao extensionista resolver conflitos, isso passa novamente pelo modelo de extensão rural que se quer propor. Se a extensão for pensada como intervenção, é

7 Este é, segundo Montero (2003), o objetivo da psicologia comunitária. Todavia, ele parece adequar-se aos objetivos de diferentes áreas que dividem esse campo de atuação. 
realmente possível que os conflitos venham a impedir a concretização de seus objetivos. Mas se a extensão for tida como um serviço personalizado a um agricultor ou a um pequeno grupo, provavelmente os interesses serão similares, o que reduz consideravelmente as chances de existir conflito. A extensão como participação poderá permitir que o poder encontre espaço para se manifestar e desse modo seja manejado. Neste caso o extensionista estará obrigatoriamente implicado no processo e terá a oportunidade de trabalhar com o poder, no sentido de favorecer para que o seu exercício não fique polarizado.

Quadro 7. Argumento 3: "O extensionista está fugindo da questão da tecnologia".

\begin{tabular}{|l|l|}
\hline $\begin{array}{l}\text { Dados } \\
\text { 1. A agricultura é uma intervenção sobre o meio natural, uma } \\
\text { intervenção através da técnica. }\end{array}$ & $\begin{array}{l}\text { Proposição (deste modo) } \\
1 . \text { Se o extensionista não for um técnico ele vai acabar } \\
\text { deixando de trabalhar aquilo que é a essência da agricultura. }\end{array}$ \\
$\begin{array}{l}\text { Garantia (pois) } \\
\text { 1. Se o extensionista não trabalhar com tecnologia quem é } \\
\text { que vai trabalhar? }\end{array}$ & $\begin{array}{l}\text { Apoio (porque) } \\
\text { 1. Porque as outras coisas todas (gestor, articulador) os outros } \\
\text { podem fazer sem ser extensionistas. }\end{array}$ \\
\hline
\end{tabular}

Neste argumento o papel do extensionista aparece como o de trabalhar com e disseminar a técnica na agricultura. Demonstra que ainda se fazem presentes os objetivos da extensão rural tradicional, ou seja, o desenvolvimento agrícola por meio da transmissão da tecnologia, os quais deram origem ao trabalho do extensionista no Brasil.

Outra questão também se coloca neste argumento: os outros profissionais que trabalham no meio rural e que não promovem a difusão da técnica na agricultura em específico, como assistentes sociais, enfermeiros, pedagogos, psicólogos, poderiam ser chamados de extensionistas? É sabido que o meio rural não é essencialmente agrícola. Seria, então, a extensão rural um campo de intervenção apenas agrícola? Apesar das propostas de mudança da política nacional de ATER e do reconhecimento de que o extensionista precisa ter uma formação interdisciplinar, ela não faz menção ao trabalho de outros profissionais, que não os oriundos das ciências agrárias, no campo da extensão rural pública.

Desse modo, ainda carece do reconhecimento da necessidade de se conjugar trabalhos em diferentes áreas na promoção do desenvolvimento rural. Esse seria um avanço significativo para a ATER pública, uma vez que a interdisciplinaridade não significa formar um "superprofissional" que agregue saberes e habilidades de uma diversidade de áreas, o que é deveras impossível. A interdisciplinaridade supõe pensar a realidade a partir de diferentes olhares e intervir em diferentes dimensões de maneira integrada, o que torna fundamental que o campo da extensão rural seja também compartilhado.

Quadro 8. Argumento 4: "É necessário repensar o ensino da extensão rural na pós-graduação".

\begin{tabular}{|l|l|}
\hline $\begin{array}{l}\text { Dados } \\
\text { 1. Os profissionais que não são das agrárias e que entram para } \\
\text { a extensão rural têm dificuldades em entender o conteúdo. }\end{array}$ & $\begin{array}{l}\text { Proposição (deste modo) } \\
1 . \text { É necessário repensar o ensino da extensão rural na pós- } \\
\text { graduação. }\end{array}$ \\
$\begin{array}{l}\text { Garantia (pois) } \\
1 . \text { É preciso desamarrar esse nó inicial. }\end{array}$ & $\begin{array}{l}\text { Apoio (porque) } \\
1 . \text { Cada vez mais vai ser característico o fato da extensão rural } \\
\text { ter turmas com diferentes profissionais. }\end{array}$ \\
\hline
\end{tabular}

Somando-se ao que foi exposto, está o argumento de que é preciso repensar o ensino da extensão rural na pós-graduação. Se ainda existe a dificuldade de agregar à extensão rural 
pública o trabalho de diferentes profissionais, no que diz respeito à formação em extensão rural, ela é disponibilizada a diferentes áreas. Porém, associado à abertura para a formação, é fundamental que se reflita quais conteúdos são adequados para serem oferecidos a uma diversidade de campos de saberes, para que a formação não tenda a priorizar uma determinada área em detrimento das demais.

De modo que o diálogo entre diferentes campos possa acontecer, faz-se necessário levar em consideração os seguintes aspectos: o que buscam os diferentes profissionais na formação em extensão rural e porque a buscam? O que objetiva a formação em extensão rural no momento em que acolhe profissionais de outros campos de saber que não as ciências agrárias? Em que sentido a sociedade está sendo beneficiada? Essas perguntas são aqui colocadas como possibilidades de reflexão.

Quadro 9. Argumento 5: "O extensionista precisa participar das instituições que pensam suas ações".

\begin{tabular}{|l|l|}
\hline $\begin{array}{l}\text { Dados } \\
\text { 1. O extensionista executa ações que ele não ajudou a pensar. }\end{array}$ & $\begin{array}{l}\text { Proposição (deste modo) } \\
1 . \text { O extensionista precisa participar das instituições que } \\
\text { pensam suas ações. }\end{array}$ \\
$\begin{array}{l}\text { Garantia (pois) } \\
\begin{array}{l}\text { 1. Se o extensionista não participa, ele fica como "fantoche" } \\
\text { nas mãos de quem decide suas ações. }\end{array}\end{array}$ & $\begin{array}{l}\text { Apoio (porque) } \\
1 . \text { O extensionista precisa lutar por aquilo que ele acredita. }\end{array}$ \\
\hline
\end{tabular}

Tradicionalmente o trabalho do extensionista estava voltado para a difusão de inovações. Seu papel era o de mediador entre a fonte e o receptor, ou destinatários. A extensão, neste caso, segundo Castro (2003), trata-se de uma ação que tem por objeto o outro, sobre o qual se descarrega o conteúdo que o ator ou a fonte desejam transmitir. Ela supõe uma intenção que está na fonte, porém não necessariamente nos receptores. Responde também a uma necessidade de quem a realiza baseada na percepção das necessidades de quem será o receptor desse ato. A fonte está convicta de que pode fazer algo e que tem poder e autoridade para fazê-lo. O extensionista entra, então, como o mediador, o que implica em intervenção sobre a realidade do outro. Ocorre que esse outro não solicitou a intervenção, talvez nem sinta a sua necessidade, o que leva o extensionista a ter que convencê-lo de sua conveniência.

Observa-se que nesse processo nem o extensionista, nem os receptores pensam qual é realmente a necessidade de determinada intervenção. Quem pensa é a fonte ou a instituição à qual o extensionista se vincula. $\mathrm{O}$ argumento propõe que o extensionista pense suas ações, participe das instituições, não apenas as execute. Porém, não fica claro se os receptores estariam incluídos no processo. $\mathrm{O}$ adequado seria dizer que o extensionista pense se suas ações possibilitam que os agricultores (neste caso não "receptores") pensem sobre suas necessidades. A proposta da ATER (MDA, 2004) é que o público-alvo participe do processo e não apenas que as instituições e o extensionista determinem quais são as ações prioritárias.

Quadro 10. Argumento 6: "Precisa-se dar mais atenção à extensão rural na graduação".

\begin{tabular}{|l|l|}
\hline $\begin{array}{l}\text { Dados } \\
\text { 1. A extensão rural é muito pouco trabalhada na graduação. }\end{array}$ & $\begin{array}{l}\text { Proposição (deste modo) } \\
1 . \text { Precisa-se dar mais atenção a extensão rural na graduação. }\end{array}$ \\
$\begin{array}{l}\text { Garantia (pois) } \\
\begin{array}{l}\text { 1. A questão do perfil profissional se desenha desde o primeiro } \\
\text { dia que se entra na universidade. }\end{array}\end{array}$ & $\begin{array}{l}\text { Apoio } \\
1 . \text { O aluno acaba tendo que correr atrás através do mestrado } \\
\text { para obter complementações. }\end{array}$ \\
\end{tabular}


Este argumento retrata o lugar que a extensão ocupa nos cursos de graduação em ciências agrárias. A necessidade de ter que se "dar mais atenção à extensão rural na graduação" demonstra a avaliação de que a formação estaria sendo insuficiente para os profissionais. Freire (1977) afirmou ser inadiável que se discuta interdisciplinarmente a assistência técnica, tomando o homem a quem serve como o centro da discussão. Apesar desta colocação ter sido feita há pelo menos três décadas, o desafio lançado por Freire (1977) para a formação dos profissionais de extensão rural é ainda atual.

\section{Representação dos argumentos sobre a necessidade de criação de um doutorado}

Quanto às opiniões sobre a necessidade de criação de um doutorado em extensão rural, três argumentações centrais foram levantadas pelos participantes que se pronunciaram: argumento 1, "O doutorado deve ser em extensão rural"; argumento 2, "O doutorado precisa trazer inovações" e argumento 3, "É necessário se pensar as instituições no doutorado.

Quadro 11. Argumento 1: "O doutorado deve ser em extensão rural".

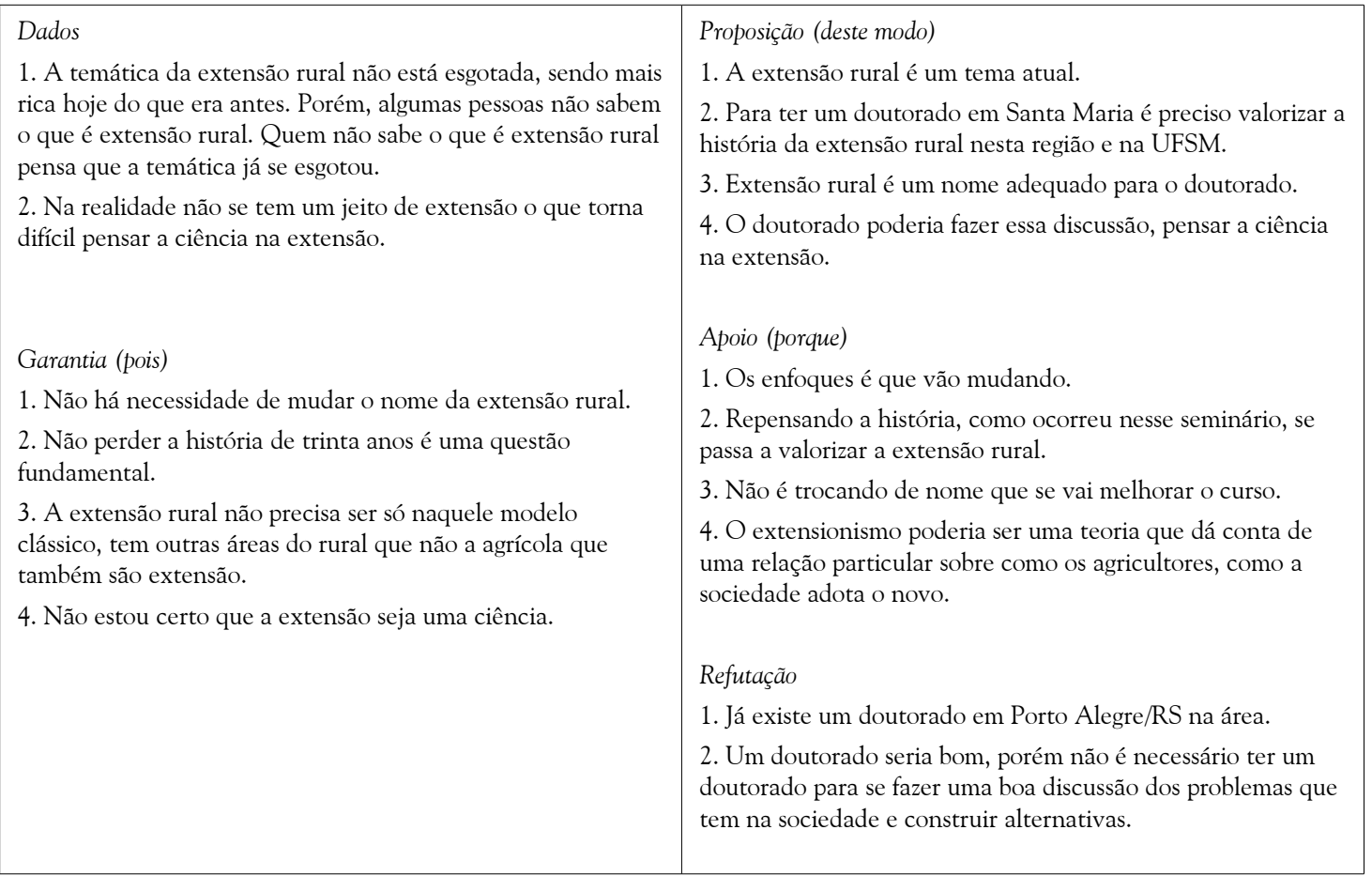

Dados de que a temática da extensão rural não se esgotou e de que é preciso valorizar sua história enquanto curso de pós-graduação são relevantes para se pensar na necessidade de possibilitar uma formação mais aprofundada na área. Aparece na refutação que "um doutorado seria bom, porém não é necessário ter um doutorado para se fazer uma boa discussão dos problemas que têm na sociedade e construir alternativas", ou seja, a formalização do processo não vem significar que discussões relevantes na área não estejam já acontecendo. 
Quadro 12. Argumento 2: "O doutorado precisa trazer inovações".

\begin{tabular}{|l|l|}
\hline $\begin{array}{l}\text { Dados } \\
\text { 1. A sociedade precisa de inovações. }\end{array}$ & $\begin{array}{l}\text { Proposição (deste modo) } \\
1 . \text { Um curso de doutorado tem que se importar no sentido de } \\
\text { trazer inovações técnicas. }\end{array}$ \\
$\begin{array}{l}\text { Garantias (pois) } \\
\text { 1. A sociedade tem que ser convidada a inovar. }\end{array}$ & \\
\hline
\end{tabular}

Este argumento demonstra uma característica da extensão rural tradicional, ou seja, o aumento da produção a partir da implantação de inovações tecnológicas. A mudança proposta pela política de ATER pode não ser compartilhada por todos os extensionistas, de modo que ainda perpassa a ideia de extensão segundo os moldes do paradigma tradicional. Inovações tecnológicas devem ser sempre bem-vindas. O que não pode ocorrer é que elas fiquem acessíveis apenas para uma minoria de agricultores.

Quadro 13. Argumento 3: "É necessário se pensar as instituições no doutorado".

\begin{tabular}{|c|c|}
\hline Dados & Proposição (deste modo) \\
\hline $\begin{array}{l}\text { 1. Nenhum profissional da extensão rural trabalha } \\
\text { autonomamente. }\end{array}$ & $\begin{array}{l}\text { 1. Torna-se necessário uma linha de pesquisa no doutorado } \\
\text { que trate das instituições as quais se vinculam os }\end{array}$ \\
\hline $\begin{array}{l}\text { 2. As instituições é que acabam imprimindo o ritmo de } \\
\text { trabalho. }\end{array}$ & extensionistas. \\
\hline & Apoio (porque) \\
\hline Garantia (pois) & 1. O profissional trabalha por intermédio das instituições nas \\
\hline $\begin{array}{l}\text { 1. A capacidade individual consegue alterar um determinado } \\
\text { espaço e desenvolver uma ação positiva, mas isso não é de } \\
\text { maneira homogênea dentro dos contextos das instituições. }\end{array}$ & \\
\hline
\end{tabular}

No entanto, embora objetivem a mudança, os extensionistas não estão certos se a proposta realmente permitirá isso, especialmente no papel do extensionista - mediador entre a fonte e os receptores -, o que os instiga a buscá-la nas instituições a que estão vinculados. A questão que fica é se a extensão rural está sendo pensada junto a seus destinatários e se os extensionistas acreditam que isso seja possível. As evidências dos argumentos dos participantes não indicam que essa seja uma ideia compartilhada tanto quanto é proposta pela política nacional de ATER.

\section{Considerações finais}

Retomando de maneira sintetizada os resultados aqui apresentados, verificou-se no primeiro eixo de discussão a ênfase na questão da diferenciação da realidade rural, bem como o papel da extensão rural na condição social dos agricultores. Além disso, a crise de métodos e teorias adequadas para interpretar a realidade aparece como uma dificuldade a ser superada no campo da extensão.

No segundo eixo, relativo ao perfil do extensionista rural, foi argumentado que ele necessita fazer uma leitura adequada da realidade social, além de manejar conflitos. Questões como tecnologia e participação das instituições que pensam suas ações foram levantadas. Por outro lado, a formação na pós-graduação e na graduação também necessitaria ser reconfigurada. 
Quanto ao eixo três, que discutia a criação de um curso de doutorado, houve a defesa de que ele fosse em extensão rural. Temáticas como inovação tecnológica e instituições poderiam fazer parte das discussões do curso.

Os resultados apontam que, com o fim da era dos pacotes tecnológicos, a extensão rural encarregada de transmiti-los aos receptores é solicitada a reconfigurar seus fundamentos e sua prática. A realidade rural, com toda a sua heterogeneidade, que não é apenas geográfica, coloca-se como um desafio. Os resultados negativos da modernização da agricultura evidenciam uma responsabilidade a ser compartilhada pelos profissionais da extensão rural. Quem é o extensionista rural? Como fazer extensão rural? São questionamentos que emergem no cotidiano diário.

A interdisciplinaridade desponta como uma possibilidade, porém, está longe de ser entendida pela via do diálogo. O que se observa é que a extensão rural busca agregar saberes de áreas distintas, a fim de formar profissionais que deem conta de diferentes necessidades. No entanto, o compartilhamento do seu campo de atuação com profissionais de diferentes áreas, que não as tradicionais, ainda não é uma realidade na extensão rural pública.

Cabe lembrar que o meio rural não se caracteriza como um espaço essencialmente agrícola. A preocupação do extensionista pura e exclusivamente com a técnica pode ser insuficiente para atender a diversidade de necessidades desse contexto. Sendo assim, esse é mais um fator que contribui para que se argumente a favor da abertura e do reconhecimento do campo da extensão rural tanto privada, quanto pública para profissionais de diferentes áreas, de modo que as comunidades nele circunscritas possam usufruir de conhecimentos específicos que venham ao encontro das suas diferentes necessidades.

\section{Referências}

Anjos, F. S. dos (2003). Pluriatividade e desenvolvimento rural no sul do Brasil. Cadernos de Ciência Ė Tecnologia, 20 (1), 11-44.

Beltrán, L. R. (1971). La "revolución verde" e el desarrollo rural latinoamericano. Desarrollo Rural en las Américas, 3 (1), 5-26.

Castro, E. G. (2003). El punto de inserción. In R. Thorton \& G. Cimadevilla(Orgs.), La extensión rural em debate (pp. 41-65). Buenos Aires: Ediciones INTA.

Dufumier, M. (1996). Les projets de développement agricole: manual d'expertise. Paris: Khartala/CTA.

Farrington, J., Christoplos, I., Kidd, A. D. \& Beckman, M. (2002). Extension, poverty and vulnerability: the scope for policy reform. London: Overseas Development Institute.

Freire, P. (1977). Extensão ou comunicação? Rio de Janeiro: Paz e Terra.

Graziano da Silva, J. (1985). O que é a questão agrária? São Paulo: Brasiliense.

Graziano da Silva, J., Del Grossi, M. \& Campanhola, C. (2002). O que há de novo no rural brasileiro. Cadernos de Ciência E Tecnologia, 19 (1), 37-67.

Liakopoulos, M. (2002). Análise argumentativa. In M. W. Bauer \& G. Gaskel (Orgs.), Pesquisa qualitativa com texto, imagem e som: um manual prático (3를. $\mathrm{ed}$.). Petrópolis: Vozes.

Medeiros, L. S. de (1989). História dos movimentos sociais no campo. Rio de Janeiro: FASE.

Ministério do Desenvolvimento Agrário (MDA), Secretaria da Agricultura Familiar (SAF), Grupo de Trabalho ATER. (2004). Política Nacional de Assistência Técnica e Extensão Rural. Brasília.

Montero, M. (1994). Consciousness raising, conversion, and deideologization in community psychosocial work. Journal of Community Psychology, 22, 3-11.

Montero, M. (2003). Teoría y práctica de la psicologia comunitária: la tensión entre comunidad e sociedad. Buenos Aires: Paidós. 
Pinto, J. B. (1973). Extensión o educación: una disyuntiva crítica. Desarrollo Rural en las Américas, 5 (3), 165- 186.

Sarriera, J. C. (2008). Análisis de las necesidades de un grupo o comunidad: la evaluación como proceso. In E. Saforcada \& J. C. Sarriera (Orgs.), Enfoques conceptuales y técnicos en psicología comunitaria. Buenos Aires: Paidós.

Schneider, S. (1999). Agricultura familiar e pluriatividade. Tese de Doutorado, Programa de Pós-Graduação em Sociologia, Universidade Federal do Rio Grande do Sul, Porto Alegre.

\section{Endereço para correspondência}

evelinefavero@yahoo.com.br, sarriera@terra.com.br 